\title{
全自動測定による高難度結晶からの構造解析
}

\author{
東京医科歯科大学難治疾患研究所 沼本修孝
}

\section{Nobutaka NUMOTO: Structure Determination from Protein Crystal Clusters by Fully Automatic Data Collection}

Recent advance in the automatic data collection systems at the synchrotron facilities enable us to obtain high quality diffraction data without on-site operation. Structural determinations from the crystal clusters of small proteins were successfully achieved with microfocus beam, the automated data-collection system, and the data-processing pipeline in SPring-8.

\section{1. はじめに}

近年の国内放射光施設での回折データ収集は高度に 自動化され，通常，来所する必要なくこれまでと同等以 上の精度でデータを取得できるようになった。筆者も， かれこれ2年近く放射光施設には足を運んでいないが, それでなんの問題もなく研究は進んでいる。 それどころ か, 自動測定, 自動解析でなければ構造決定は難しかっ ただろうと思われる事例までも経験することができた。 本稿ではそのような例として, SPring-8の高輝度微小 フォーカスビームとその利点を最大限に活かした自動 デー夕収集システム ZOO, ${ }^{1)-3)}$ および同システムに内包 されている自動データ解析パイプライン $\mathrm{KAMO}^{4), 5)}$ によ り, クラスター状結晶をそのまま用いた, これまでの常 識を覆すような構造決定の例を紹介する.

なお本稿で取り上げる手法はZOOシステムの「Multi 測定 (SWSX : Small Wedge Synchrotron Crystallography)」 によるものであり, 本来主に膜タンパク質の微小結晶から の構造決定のために開発されていたもので, その技術やプ ログラムは以前から使用されていたものである. 筆者自身 も，そのような特殊な技術と思い达んでしまっていたが, 通常の可溶性タンパク質の結晶構造解析にもおおいに適 用できるものであることを思い知らされた次第である.

\section{2. 高度にクラスター化した結晶からの構造決定}

1つ目の例では, 解析対象試料は分子量 $14 \mathrm{kDa}$ のタン パク質ドメインである. 小型のドメインではあるが, 分子 内に三カ所ジスルフィド結合を有し, 大腸菌で大量発現 させたのち非可溶性画分から回収して非効率なリフォー ルディングにより調製する必要があり, 収量の観点から 結晶化は難航した。ようやく得られた結晶も, 図1Aのよ うなひどいクラスター状の結晶であり, 構造解析はとて も不可能であると思われた， タンパク質の結晶であるか どうかを確認するためにX線回折実験を行ったところ,
同心円状の, いわゆる粉末結晶からの回折パターン様の 回折像が得られたが，低角から回折リングが観測されて おり, タンパク質由来の回折像であることはわかった。

これに勇気づけられ結晶化条件の最適化を試みたもの の, 試料量に限りがあって多くの条件を試せなかったこ ともあり, 図1Bのような依然多数の結晶からなるクラ スター状のものが得られるに留まっていた．しかしなが ら, このような結晶は再現良く得られ, サイズも直径で 200 400 $\mu \mathrm{m}$ 程度と比較的大型であり, 最近の SPring-8 の高輝度微小フォーカスビームを用いれば, 単結晶領域 にビームを照射することは不可能ではないとも思われた。

筆者は最初, このようなクラスター結晶を物理的に砕 いて小さな結晶に分割してしまえば, 膜タンパク質の微 結晶による構造解析の手法が援用できるのではないかと 考えたのだが, ビームライン担当者に相談したところ, 結晶に与える物理的ダメージの心配もあるため, まずは このままで微小フォーカスビームによって単結晶として データ収集が可能か確認するのが得策だろうとのこと だった。早速BINDSの支援に申請し，ビームタイムを確 保して実験を行ったところ, たった一度のビームタイム で構造解析まで完了してしまった（図1C).

このときのデータ収集は次のとおり行った。まず, 図1Bのような結晶をクライオプロテクタント置換後, 通 常行うようにクライオループに1つ拾い, 液体窒素で凍 結した。これを14個Unipuckに装填して SPring-8に送付 し、データ収集を依頼した。データ収集は, SPring-8の

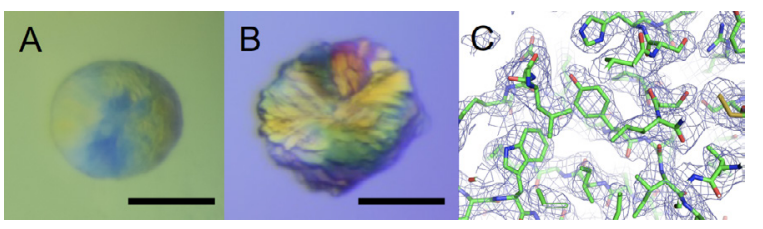

図1 $14 \mathrm{kDa}$ タンパク質の結晶構造解析. (Crystal structure analysis of a $14 \mathrm{kDa}$ protein.) (A, B) クラスター結晶. スケールバーは $0.2 \mathrm{~mm}$. (C) 結晶構造と電子密度図. 
A

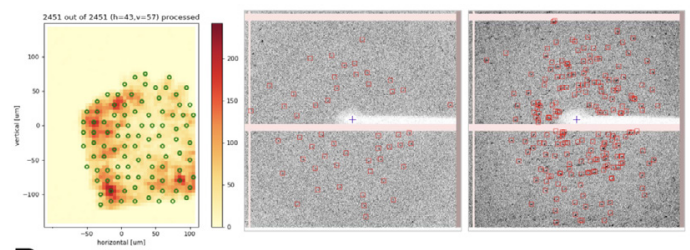

B

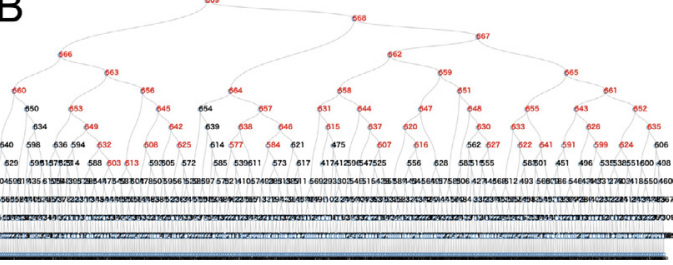

図2 デー夕収集と解析. (Data collection and process) (A) ZOO システムによる結晶のラスタースキャン結果.

（B）KAMOによる small wedge データの階層的ク ラスタリング。

自動測定システムであるZOOの「Multi測定」モードに より行った. これは本来, 1 つのクライオループに数十 以上の微小な結晶がランダムな方位で存在しているこ とを念頭に, これらの微結晶から $5 \sim 10$ 分のデー夕を収 集して mergeすることにより，また必要であれば同様の データを複数のループにわたって収集し完全なデータ セットを得る方法である. 上述のように, 膜タンパク質 の主にLCP 法による微結晶からのデー夕収集で多くの 成功を収めてきた手法である.

今回の結晶は,「ひとつの塊」であるが, 内実はさまざ まな方位を向いた微小な単結晶からなるクラスターであ るとみなし, 上記の方法を適用することとした. SPring-8 BL32XUにおいて, $5 \mu \mathrm{m} \times 5 \mu \mathrm{m}$ のビームサイズを用い

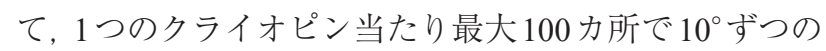
small wedgeデータ測定を行う設定とした. はじめにラス タースキャンにより回折点が記録された位置を記録して スコア付けがされ (図2A左), 上位のものについてデー 夕測定が行われる、X線の照射位置により，比較的良好 な回折像が得られる場合 (図2A中央) とそうでない場合 (図2A右) が見られるが, 奥行き方向に結晶が重なってし まっている例も多いためと思われる。14個のループを用 いたため, 合計 1,400 の small wedge データが収集された。

これらのデータは, ZOOシステムに含まれているプロ グラム KAMOにより，指数付けと積分がなされた後に取 捨選択され, 格子定数または強度相関による階層的クラ スタリングが行われた、ユーザーはどちらのクラスタリ ング結果を使用するか選択できる. 本稿では, 格子定数 ベースのクラスタリングの結果を示す (図2B)，1,400の うち 670 デー夕がmergeの対象となり,このうち最終的 に 582 データが使用され， $2.5 \AA$ 分解能のフルデータとし て分子置換法で構造決定を行うことができた（図1C).

デー夕収集の統計值 (表1) は, 通常の1つないし数個 の単結晶からのデータ収集時のそれとは様相が異なって
表1 データ収集および解析の統計值. (Data statistics.)

\begin{tabular}{|c|c|c|}
\hline & $14 \mathrm{kDa}$ protein & $15 \mathrm{kDa}$ protein \\
\hline Spacegroup & $C 2$ & $P 6_{1}$ \\
\hline Resolution $(\AA)$ & $50 \sim 2.50(2.59 \sim 2.50)$ & $60 \sim 2.01(2.13 \sim 2.01)$ \\
\hline Completeness $(\%)$ & $100(100)$ & $99.5(99.5)$ \\
\hline Redundancy & 96.4 & 6.7 \\
\hline$I / \sigma(I)$ & $15.2(1.4)$ & $5.5(1.6)$ \\
\hline$R_{\text {meas }}(\%)$ & $82.3(>100)$ & $36.2(129)$ \\
\hline $\mathrm{CC}_{1 / 2}(\%)$ & $99.8(84.7)$ & $97.4(56.0)$ \\
\hline$R / R_{\text {free }}(\%)$ & $23.5 / 25.9$ & $20.1 / 23.8$ \\
\hline
\end{tabular}

いる. 特に，等価な反射の一致度を表す $R$ 值が低角領域 から高い值を示しているため, overallでも高い值となっ ている. 今回のデータでは, 結晶の空間群が $C 2$ と対称 性が低いにもかかわらず, データの圥長性 (redundancy) は 100 近いため, 必然的に $R$ 值も高い值になったものと 思われる。このようなデー夕収集法では，もはや $R$ 值は データの質を判断する際にあまりよい指標にならないよ うであり， $\mathrm{CC}_{1 / 2}$ を指標にするほうが適切であるようであ る.一方, 非常に高い redundancyの扔かげで $I / \sigma(I)$ は広 角側でも十分な值を保って㧍り, 今回は $\mathrm{CC}_{1 / 2}$ と $I / \sigma(I)$ を指標に分解能のカットオフを $2.5 \AA$ とした. このデー 夕で分子置換法により問題なく初期位相が決定でき，モ デル修正と精密化を数サイクル行って, $2.5 \AA$ 分解能と して妥当な $R, R_{\mathrm{free}}$ 值を得た（表1). 得られた電子密度 図, 構造モデルの妥当性の検証デー夕も順当なものが得 られており, 問題なく構造解析が完了できたと言える。

繰り返しになるが, 以上の構造解析が, 事前に入念な 予備的回折実験などを行うことなく, 来所することもな く,たった一度の全自動測定ビームタイムで完了した。

\section{3. 小さなクラスター結晶からの構造決定}

次の例も, 分子量 $15 \mathrm{kDa}$ のさなタンパク質ドメインで ある. 初回の結晶化スクリーニングで, 図3Aのような微細 な針状結晶のクラスター状のものが得られた. ビームタイム 直前になって得られたため, 結晶化の再現性確認や条件 最適化をする間もなく，とりあえずそのまま回折実験に供 した．例によって全自動測定のビームタイムであり，すでに この回の測定に割り当てる結晶(の数) は決まっていた，夕 ンパク結晶であるか否かの判別がつけば上々という程度の 気持ちで, クライオピンでクラスターごと無造作にすくい上 げ(図3A)，その1つのクライオピンだけを，予定されてい た結晶を1つ犠牲にして割り込ませてSPring-8に送付した。

全自動測定のビームタイムであるので, 当たり前であ るが測定条件は事前に指定することになる。単純に反射 チェックができればよいと, スナップショットを撮るだけ のモードに指定することも考えたが, 前回の成功体験が 頭をよぎり, どうせならばと半ば興味本位で「Multi測定」 を指定した. 結果は驚いたことに $2.0 \AA$ 分解能の完全デー 夕となり, 分子置換法により構造決定することができた。 


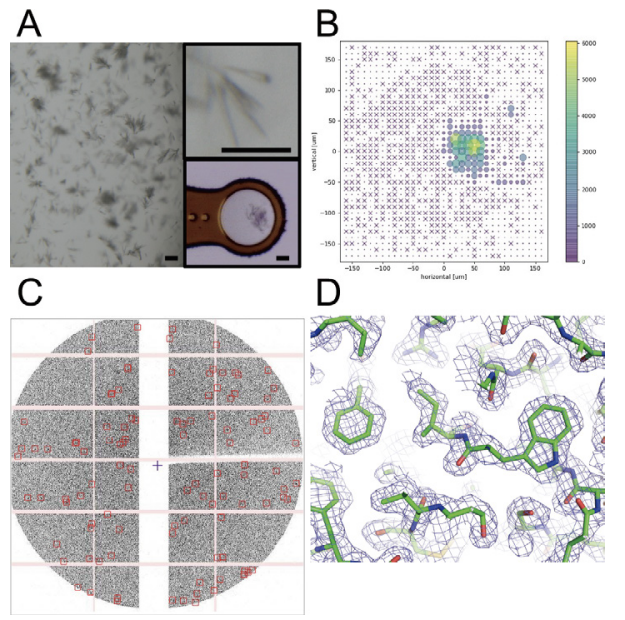

図3 $15 \mathrm{kDa}$ タンパク質の結晶構造解析. (Crystal structure analysis of a $15 \mathrm{kDa}$ protein.) (A) 微結晶のクラス ター。スケールバーは $50 \mu \mathrm{m} .(\mathrm{B}, \mathrm{C}) \mathrm{ZOO}$ システ ムによる結晶のラスタースキャン結果. (D) 結晶 構造と電子密度図.

回折実験はSPring-8のBL45XUで行い, $10 \mu \mathrm{m} \times 10 \mu \mathrm{m}$ のビームサイズを用い, 1つのクライオピン当たり最大 50 カ所で $10^{\circ}$ ずつのデータ測定を行う設定とした. 結果 として,19個の small wedgeデータが収集され (図3C), 15 のデータが mergeの対象となって格子定数による階 層的クラスタリングが行われ, 13 のデータを選択して mergeすることで $2.0 \AA$ 分解能の完全データが得られ, 構 造決定をすることができた（図3D）．この例では空間群 が $P 6_{1}$ と対称性が高かったことが幸いし，このような少 数の small wedge データからでも overall の completeness が $99.5 \%$, redundancyが 6.7 と問題のない完全データと なった（表1)。データ収集に要した時間は，たった $1 つ$ のクライオピンということで, わずか 8 分強であった。

\section{4. 自動測定のパラメータ設定}

本稿の二例はいずれも, SPring-8の自動測定システム ZOOによる「Multi測定」モードでデー夕収集を行った。 ZOO システムは高度に洗練されているため, 事前にユー ザで指定すべきパラメータは驚くほど簡略化されてい るが,「Multi測定」モードならではの注意点も多少ある。 1つはビームサイズの選定である。一例目の大型クラス ター結晶のデータ収集では, 実は筆者は当初さしたる思 慮もなく, せっかく BL32XUなのでと思い, 利用できる 最小ビームサイズである $1 \mu \mathrm{m} \times 1 \mu \mathrm{m}$ のビームタイムを 指定していた，測定前にビームライン担当者から，反射 チェックだけでなく, デー夕収集も視野に入れるなら, $5 \mu \mathrm{m} \times 5 \mu \mathrm{m}$ 以上のビームサイズを推奨するとアドバイ スをいただいた。あまりにも微小なビームサイズでは, 回折点の分離がよくなるメリットよりも, 放射線損傷の 影響により分解能が低下するデメリットのほうが大きく なってしまうようである, 通常は, 微結晶のサイズと同 日本結晶学会誌 第 63 巻 第 3 号 $(2021)$
等程度がよいようである。

もう1つはまさに「Multi測定」モード特有のパラメータである が, 最短の露光点間距離を規定する「Crystal size」というパ ラメータである. 詳しくは SPring-8構造生物ビームラインのWeb siteにあるマニュアル (http://bioxtal.spring8.or.jp/ja/users/Auto/ PXBL_Auto_sample_sheet_manual_ja.pdf)を参照いただきた いが, 結晶サイズより若干大きめに設定しておくことで, 隣接する照射点が接近しすぎることに起因する, 隣同士の 露光点由来の放射線損傷を防ぐことができるようである. 本マニュアルは非常に丁寧な記述がなされているので, 全 自動測定を利用する前には面倒がらずに熟読することをお

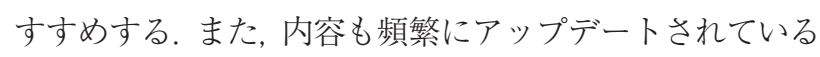
ので,できればこまめに再読することをおすすめする。

\section{5. おわりに}

筆者はすでに放射光施設での回折実験については完全 に自動測定に依存しており, 自分で測定するよりも, 自動測 定のほうがよいデー夕を取得できると確信している。 もちろ ん自動測定と同じことを手動で行うこともできないことはな いが, 時間効率と人為ミスの可能性を考えればまったく利 するところがない. さらに, このようなクラスター結晶から の構造決定まで一度のビーム夕イムで可能となると, 十分に 構造解析が可能であるにもかかわらず, これまでの経験か ら回折実験を行うこともなく諦めてしまっているものがある のではないかという思いにかられる. 今後, 結晶化実験と デー夕収集の戦略が根本的に変わるのではないだろうか.

本構造解析では, 理化学研究所の平田邦生博士, JASRI の仲村勇樹博士に実験前の条件設定から実験後のフォ ローアップまで大変お世話になりました。 また平田博士 には本稿に目を通していただき, 的確な助言をいただき ました。この場をお借りしてお礼申し上げます。

\section{文 献}

1) K. Hirata, et al.: Acta Cryst. D75, 138 (2019).

2) 平田邦生：日本結晶学会誌 62, 84 (2020).

3) 平田邦生, 山本雅貴 : 生物物理 59, 215 (2019).

4) K. Yamashita, et al:: Acta Cryst. D74, 441 (2018).

5) 山下恵太郎：日本結晶学会誌 59, 207 (2017).

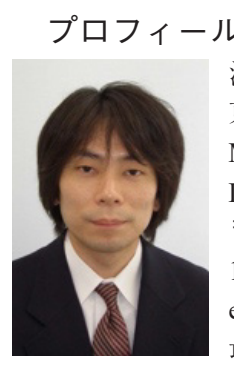

沼本修孝 Nobutaka NUMOTO 東京医科歯科大学難治疾患研究所

Medical Research Institute, Tokyo Medical and Dental University

干 113-8510 東京都文京区湯島 1-5-45

1-5-45 Yushima, Bunkyo-ku, Tokyo 113-8510, Japan e-mail: numoto.str@mri.tmd.ac.jp

最終学歴: 京都大学大学院理学研究科, 博士 (理学)

専門分野: 構造生物学

現在の研究テーマ: 免疫細胞共受容体の構造生 物学

趣味: 読書 